\title{
THE ORGANIZATION OF TOURIST SERVICES OF THE SECOND WORLD WAR MUSEUMS IN POLAND AND UKRAINE
}

\section{ОРГАНІЗАЦІЯ ТУРИСТИЧНИХ ПОСЛУГ МУЗЕЇВ ІСТОРІЇ ДРУГОї СВІТОВОЇ ВІЙНИ В ПОЛЬЩІ ТА УКРАЇНІ}

\author{
Byelikova Maryna \\ Candidate of Historian Sciences, Associate Professor, \\ Senior Lecturer at the Department of Tourism, \\ Hospitality and Restaurant Business, \\ Zaporizhzhia Polytechnic National University
}

Hres-Yevreinova Svitlana

Candidate of Economic Sciences, Senior Lecturer at the Department of Tourism, Hospitality and Restaurant Business, Zaporizhzhia Polytechnic National University

Бєлікова М.В.

кандидат історичних наук, доцент, доцент касредри туристичного, готельного, ресторанного бізнесу, Національний університет «Запорізька політехніка»

Гресь-Євреінова С.В. кандидат економічних наук, доцент каседри туристичного, готельного, ресторанного бізнесу, Національний університет «Запорізька політехніка»

The audio guides and guided tours are strengths of the provision of services in the Second World War Museums in Kyiv and Gdansk. However, the process of providing museum services in the National Museum of the History of Ukraine in the Second World War needs certain changes. It is necessary to adopt the West European museum price policy, where cost is higher, and photography services are free. Tourists are interested in buying tickets online because it will decrease the waiting time before service provision. It would be relevant to add English and Russian texts to museum pieces. It is important to develop special offers for tourists and their online availability. There is a need to motivate the museum staff who should propose additional and exclusive services for visitors, for example, visiting the viewing decks of the sculpture "Motherland". The financial trouble has reached an acute stage, that's why it will be necessary to look for the ways of optimization of the museum management and the organization of tourist services of the Second World War Museum in Ukraine.

Key words: organization of tourist services, museum management, annual attendance of museums, museum services, special offers.

В результаті компаративного аналізу організації туристичних послуг в музеях Другої світової війни в Києві та Гданську виявлено, що їхніми сильними сторонами є аудіогіди та надання екскурсійних послуг для туристів, зокрема іноземних. Одночасно прочес надання музейних послуг Національного музею історії України у Другій світовій війні потребує змін. Для ексклюзивних послуг має бути розроблена маркетингова стратегія просування в Інтернеті. Туристи є більш вимогливі у порівнянні з шкільною та студентською музейною аудиторією, оскільки отриманий досвід дозволяє їм порівнювати послуги різних музеїв, тому існує необхідність мотивувати персонал, щоб той пропонував відвідувачам додаткові та ексклюзивні послуги музеїв разом з придбанням квитків та замовленням екскурсій. I (підйом на оглядові майданчики скульптури Батьківщина-мати). Фінансові труднощі, які постали нині перед музеєм, зумовлюють необхідність пошуку шляхів оптимізації системи управління та організації туристичних послуг Музею історії України в Другій Світовій війні. Під час встановлення цін на послуги музеями враховувались середні ціни на музейні послуги у відповідних країнах. Встановлювати низьку вхідну плату і завищені ціни на аматорські фрото та відеопос- 
луги Музею історії України у Другій світовій війні в Києві є вважаємо недоцільним: треба переймати досвід цінової політики музеїв Західної Європи, де більш висока ціна, а включені до чіни вхідного квитка безкоштовні фротопослуги є більш привабливим рішенням для туристів. Крім того, туристи зацікавлені в придбанні квитків он-лайн, що відвідування меморіального комплексу зробить більш зручним, оскільки це зменшить час очікування перед наданням послуг. В музеях Європи вивчають, які туристи їх відвідують, і поряд з етикетажем мовою країни розміщують інформацію та інструкції на відповідних мовах. Було б доречним доповнити експонати текстами англійською та російською мовами на території музейного комплексу. Отже, існуючі системні недоліки організації музейних послуг для іноземних туристів в Національному музеї історії України у Другій світовій війні досі не вирішені, тому є важливим розробити спецпропозиції для туристів, які пропонувати онлайн.

Ключові слова: організація туристичних послуг, музейний менеджмент, річна відвідуваність музеїв, музейні послуги, спецпропозиції.

Аудиогиды и экскурсионные услуги являються сильными сторонами организации услуг в музеях Второй мировой войны в Киеве и Гданьске. Тем не менее определенные изменения требуются процессу предоставления музейных услуг в Национальном музее истории Украины во Второй мировой войне. Необходимо перенимать опыт ценовой политики музеев Западной Европы, где более высокая цена и бесплатные фотоуслуги. Туристы заинтересованы в приобретении билетов онлайн, поскольку это сократит время ожидания перед предаставлением услуг. Было бы уместным дополнить экспонаты текстами на английском и русском языках. Важным является разработка спецпредложений для туристов и предложение их онлайн. Существует необходимость мотивировать персонал, чтоб тот предлагал посетителям дополнительные и эксклюзивные услуги музеев (подъем на смотровые площадки скульптуры «Родина-мать»). Финансовые трудности, которые возникли сейчас перед музеем, обусловливают необходимость поиска путей оптимизации системы управления и организации туристических услуг Музея истории Украины во Второй мировой войне.

Ключевые слова: организация туристических услуг, музейний менеджмент, годовая посещаемость музеев, музейные услуги, спецпредложения.

Statement of the problem in the general form and its connection with important scientific or practical tasks. The organization of tourist services consists of travel agencies services, transport services, accommodation and catering services, excursion services and others, in particular, museum services are studied among them the least. At the same time, museum services are important in the organization of tourist services. The organization of tourist services in the Second World War Museums in Poland and Ukraine is applied, and the research deals with the description and comparative analysis of services of two museums, which are oriented on tourists and development of relevant museum products.

The analysis of recent researches and publications which initiated the solution of this problem and on which the author relies. The problem of the tourist services organizations is considered in the theoretical and applied researches of marketing and management in tourism $[1$, p. $64 ; 2 ; 3 ; 4 ; 5]$. The organization of tourist services in museums is analyzed in the context of museum management and other museum forms of activity. Babaritska V.K. analyzed theory and practice of the guided tours and museum services, but her studies are not dedicated to the specificities of guided museum tours [6]. Gorishevskiy P.A. is one of the first scientists who has brought into science and defined the notion of the basic and additional museum services [7]. Gorishevskiy P.A., Rutinskiy are supporters of the concept of partnership in the relations between museums and travel agen- cies; the scientists believe their cooperation in tour services would be expedient as their autonomous activity is less advantageous [7, 8]. The basic forms of museum activity with visitors - guided tours, lectures, consultations - are analysed by Yureneva T. Museum guided tour is well-defined by the researcher, it is a collective museum examination with an original route accompanied by the guide for the cognitive, scientific and educational purposes for the satisfaction of the aesthetic taste in free time [9]. Savchenko A. concluded the usual museum schedule would be changed and done more comfortable for visitors, and museum products would be sold in beautiful packs in the atmosphere of relevant topic exposition [10]. Modern changes in the tourist sphere need more flexible museum activity in the organization of museum services. Therefore, practical studies of the organization of museum services are actual for using of experience of tourist-oriented museums.

The formation of aims of the article (targets). The purpose of the article is the comparative analysis of museum services of the National Museum of the History of Ukraine in the Second World War in Kyiv and the Museum of the Second World War in Gdansk.

Presentation of main research material with a full substantiation of the scientific results. The priority museum task is the satisfaction of the needs of their clients, including local people, businessmen, and tourists. The National Museum of the History of Ukraine in the Second World War (460 - 902 thousand) occupies the sec- 
ond place in terms of attendance among museums of Ukraine after the Kyiv-Pechersk Preserve (965 thousand - 1 million visitors annually). In the period from 2013 to 2014, the attendance of the National Museum of the History of Ukraine in the Second World War was reduced by $35.51 \%$ that can be explained by a decrease in the tourist flows caused by the ATO effects in the country. In 2015, the attendance increased by $95.81 \%$ due to the growth of the domestic tourist flow and $33.45 \%$ of free visitors. In 2016, the attendance dropped by $28 \%$ - museum experts explain it happened due to the changes in the mood of the museum audience because of military actions in the east, and today it is not for visiting museums.

It has an instantly recognizable logo of an image of the Motherland Monument, which is a part of the memorial complex. The logo is presented on the website and souvenirs. The image of the logo corresponds to the museum focus [11].

The main museum services of the National Museum of the History of Ukraine in the Second World War include an entrance fee for an independent review of the expositions (the main one $20 \mathrm{UAH}$ (0.69 euros) and "On foreign wars" - $10 \mathrm{UAH}$ (0.35 euros) per adult); excursion service for one person - the main exposition is $60 \mathrm{UAH}$ (2.17 euros) and "On foreign wars" $20 \mathrm{UAH}$ (0.69 euros), in English - $100 \mathrm{UAH}$ (3.48 euros). Among the exclusive services, there are ascents to the observation decks of the monumental sculpture "Motherland", $36.6 \mathrm{~m}$ high, accompanied by a tour guide which cost $50 \mathrm{UAH}$ (€ 1.72), and for adults accompanied by an instructor at a height of $91 \mathrm{~m}-200 \mathrm{UAH}$ (6.89 euros). The climb takes place on the elevator and then down steps. At an altitude of $36.6 \mathrm{~m}$, you can use established binoculars with a 30x optical zoom. These services are available only in case of good weather, and due to lack of personnel and its motivation for ordering and performing, the services are not always provided.

The disadvantages of the museum complex were discovered based on authors' observations during their frequent visits and the analysis of the TripAdvisor website; on August 1, 2019, 826 reviews were posted on the National Museum of Ukrainian History in the Second World War, among which $64 \%$ of visitors appraised the memorial complex "excellent", $28 \%$ rated "good", $6 \%-$ "not bad", 1\% of visitors - "bad", 1\% - "awful" [12]. Majority liked the atmosphere of a museum institution. Most of the negative comments were written by foreign guests demanding of the museum service. They drew attention to the fact that the staff was inhospitable, there were no marks in English for the museum expositions, the toilet was dirty and not provided with consumables for visitors. These remarks are no exception, and that sort of situation is typical for the museums of Ukraine.

Today, the museum has problems with the organization of services to visitors. In addition, the percentage of state funding in the structure of the museum complex is more than $95 \%$. The disproportionate difference between public funding of museums and own revenues is the management problem for most museums in Ukraine. One cannot compare the museum complex with the Louvre, but the experience of the latter can be used. The Louvre presents itself as an example of the world's museum service, which establishes and maintains the highest international standards in the museum field; $53 \%$ of the annual budget of the Louvre is covered by its own sources (sale of entrance tickets, excursion service, sale of souvenirs, audio guides and food services, sponsorship, export of exhibitions abroad, an automatic machine for issuing funds from an account, lease of squares) [13, p. 89-90]. The Ukrainian museums should borrow the provision of additional and related services, the search for sponsors and the interest in their own opportunities for advertising its brand on the territory of the museum, the right to visit the museum free of charge for them and their family members, etc.

The paper compares the National Museum of Ukrainian History in the Second World War in Kyiv with the Museum of the History of the Second World War in Gdansk, both of which have military-historical subject (Table 1).

One of the important changes in tourism is the increase in independently organized trips. Many tourists more often organize their trips buying museum services individually. The tourist-oriented museums are ones of leaders of organizing services according to modern global standards.

There is no product, which would satisfy all clients without any exception. Museum will meet the tourist expectations if it unites the desires and motivations, advertising messages and available resources, recommendations, competitive behavior, and available travel experience.

Analysis of museum services shows their museum strength - there are developed unique products. At the same time, the National Museum of the History of Ukraine in the Second World War needs the development of organization of the services for foreign tourists and tickets sale online. Tourists' dissatisfaction with organization museum tourist services is the result of an unfortunate experience. For example, the organization of exclusive services, walk on the observation decks is a weak spot in the National Museum of the History of Ukraine in the Second World War. The systemic problem is an impossibility of performance ordering and provision of exclusive services because of lack of staff and its insufficient motivation even in the context of good weather. While, there is tourist's demand for exclusive services.

Analysis of the Second World War Museum services in Gdansk shows the museum is oriented on tourists, family and child groups. The museum develops special offer, family ticket for about 5 persons; if a family pays for every person, the museum gets additional financial resources - by $12.72 \%$ 
Comparative analysis of the Museums of the Second World War

Table 1

\begin{tabular}{|c|c|c|}
\hline Criteria & $\begin{array}{l}\text { The National Museum of the History } \\
\text { of Ukraine in the Second World War } \\
\text { in Kyivwww.warmuseum.kiev.ua }\end{array}$ & $\begin{array}{l}\text { The Museum of the Second World War } \\
\text { in Gdanskwww.muzeum1939.pl }\end{array}$ \\
\hline 1 & 2 & 3 \\
\hline $\begin{array}{l}\text { The organizational } \\
\text { structure }\end{array}$ & Functional management system & Functional management system \\
\hline $\begin{array}{l}\text { The level of staff's } \\
\text { qualification }\end{array}$ & $\begin{array}{l}\text { Leading experts who have an academic } \\
\text { degree }\end{array}$ & $\begin{array}{l}\text { Leading experts who have an academic } \\
\text { degree }\end{array}$ \\
\hline Mission & $\begin{array}{l}\text { "To accentuate the" Ukrainian factor "and } \\
\text { show the turning-point military-political } \\
\text { events of the Second World War" }\end{array}$ & $\begin{array}{l}\text { To present complex Second World War as } \\
\text { the greatest cataclysm of the XX century }\end{array}$ \\
\hline Square & $\begin{array}{l}\text { Memorial complex is } 112400 \text { sq. m, main } \\
\text { exhibition }-5000 \text { sq. } m\end{array}$ & $\begin{array}{l}\text { Building is } 23000 \text { sq. m, permanent } \\
\text { exhibitions }-5000 \text { sq. m }\end{array}$ \\
\hline Collection & 400000 items & 25000 objects \\
\hline Architecture & $\begin{array}{l}\text { The complex includes the Museum with the } \\
\text { monument "Motherland", the main square with } \\
\text { the Heroes' Alley and sculptural compositions, } \\
\text { the exhibition of military equipment and } \\
\text { weapons, the building with the exposition "At } \\
\text { the foreign wars", ATO Museum, observation } \\
\text { grounds at an altitude of } 36.6 \mathrm{~m} \text { and } 91 \\
\text { m of the monument "Motherland" where a } \\
\text { panorama of the capital of Ukraine opens. }\end{array}$ & $\begin{array}{l}\text { The building of the Museum of Modern } \\
\text { Design is divided into three levels, the past } \\
\text { hides on the underground levels of the } \\
\text { building, the present appears in the open } \\
\text { space around the building, and the future is } \\
\text { expressed in its growing performance from } \\
\text { the observation deck with a panorama of the } \\
\text { city of Gdansk }\end{array}$ \\
\hline $\begin{array}{l}\text { Conditions for } \\
\text { visitors with } \\
\text { disabilities }\end{array}$ & $\begin{array}{l}\text { The museum products for children with low } \\
\text { vision }\end{array}$ & $\begin{array}{l}\text { There are special entrance area, elevators, } \\
\text { and one free space for parking for people } \\
\text { with locomotive dysfunctions. For people } \\
\text { with low vision, there are following tactile } \\
\text { paths as their guides, a typhlographic plan. } \\
\text { Spaces around the Museum are available } \\
\text { for the visitors with guide dogs. } \\
\text { There are audioguides in sign language, } \\
\text { and audioguides offering audio-description } \\
\text { function. The stairs inside the Museum } \\
\text { building are fitted with Braille handrails } \\
\text { which enable the visually impaired visitors to } \\
\text { navigate around }\end{array}$ \\
\hline IT & $\begin{array}{l}\text { Audioguides; virtual tour on the website; } \\
\text { tours in English, Russian, Ukrainian on } \\
\text { the website IZI Travel. Watching during } 5 \\
\text { minutes the 3D video of the Motherland } \\
\text { Monument and local Kyiv and surrounding } \\
\text { area from the height of } 100 \text { meters using the } \\
\text { virtual reality technology at the cost of } 30 \\
\text { UAH. }\end{array}$ & Audioguides \\
\hline Full price ticket & $20 \mathrm{UAH}(0.69$ euros $)$ & $23 \mathrm{PL}$ (5.44 euros) \\
\hline Reduced ticket & $\begin{array}{l}5 \mathrm{UAH}(0.17 \text { euros) for students, } 3 \mathrm{UAH}(0.1 \\
\text { euros) for schoolchildren }\end{array}$ & $\begin{array}{l}16 \text { PL (3.79 euros) for schoolchildren, for } \\
\text { students under } 26 \text { years old, pensioners } \\
\text { upper } 65 \text { years, persons with disabilities }\end{array}$ \\
\hline Family ticket & $\begin{array}{l}50 \text { UAH (1.74 euros) for } 5 \text { persons with } \\
\text { guide service }\end{array}$ & $\begin{array}{l}55 \text { PL (13 euros) for maximum } 2 \text { adults and } \\
\text { children up to } 18 \text { years old }\end{array}$ \\
\hline $\begin{array}{l}\text { Additional and extra } \\
\text { services }\end{array}$ & $\begin{array}{l}\text { Audio guides for the main exposition of } 50 \\
\text { UAH (1.74 euros). Photo and video shooting } \\
30 \text { UAH (1.04 euros) and } 50 \text { UAH in the main } \\
\text { exposition. In the museum shop you can buy } \\
\text { souvenir plates and magnets with the logo } \\
\text { of the museum, posters, leaflets, museum } \\
\text { editions, military uniforms and equipment } \\
\text { of the Second World War, virtual tour discs, } \\
\text { as well as of the Second World War and the } \\
\text { Afghan War. The museum provides meals at } \\
\text { the cafe. A list of non-core related services is } \\
\text { outlined on the site }\end{array}$ & $\begin{array}{l}\text { Audio guides for } 5 \text { PL (1.18 euros) in Polish, } \\
\text { English, French, German, Russian. Photo } \\
\text { and video recording is free. Parking for } \\
\text { visitors of the museum is free for } 3 \text { hours, } \\
\text { extra hours are paid } 5 \text { PL per hour. Library } \\
\text { services }\end{array}$ \\
\hline
\end{tabular}


Ending of Table 1

\begin{tabular}{|c|c|c|}
\hline 1 & 2 & 3 \\
\hline Exclusive services & $\begin{array}{l}\text { Rising on the observation decks ( } 50 \\
\text { (1.74 euro) and } 200 \text { UAH ( } 6.95 \text { euro)). } \\
\text { Visiting helicopter Mi-24 with the option to } \\
\text { control the blades and the audio of the battle, } \\
\text { the plane Li- } 2 \text { with a review of documentary } \\
\text { films, MiG-23 fighter for } 5 \text { UAH (0.17 euros) } \\
\text { for each object }\end{array}$ & Exclusive services are not available \\
\hline $\begin{array}{l}\text { Programs for } \\
\text { children }\end{array}$ & $\begin{array}{l}\text { Guide tours for different age groups } \\
\text { of schoolchildren; master classes for } \\
\text { schoolchildren of different age groups } \\
\text { for making leaf triangles, paper cranes, } \\
\text { poppy flowers; Outgoing museum lessons } \\
\text { are in the format of the game with the } \\
\text { demonstration of museum items, quizzes } \\
\text { and gifts; meeting with schoolchildren in the } \\
\text { museum living room in English. There is the } \\
\text { board game "2364" for teenagers and adults } \\
\text { from } 14 \text { years old (from } 5 \text { to } 10 \text { persons). } \\
\text { The players get person markers of origin, } \\
\text { education, skills and special acquaintances. } \\
\text { The players are waited hard trials and } \\
\text { decision-making which make persons } \\
\text { heroes or enemies of the people. }\end{array}$ & $\begin{array}{l}\text { The "Time travel" is a part of the Museum's } \\
\text { permanent exhibition addressed at children } \\
\text { below the age of } 12 \text {. }\end{array}$ \\
\hline Social networks & Facebook & Facebook, YouTube, Instagram \\
\hline Marketing policy & $\begin{array}{l}\text { Programs for schoolchildren and students, } \\
\text { special pricing for this segment of visitors } \\
\text { are developed. Tariffs for excursion services } \\
\text { depend on the size of the group, and ones } \\
\text { in a foreign language are more expensive. } \\
\text { The museum needs to develop a marketing } \\
\text { strategy for the promotion of exclusive } \\
\text { services via the Internet }\end{array}$ & $\begin{array}{l}\text { The museum "promotes" the site via the } \\
\text { Internet, provides an opportunity to order } \\
\text { tickets online for individuals (up to } 9 \text { people); } \\
\text { provides an opportunity to visit the Museum } \\
\text { free of charge on Tuesday. The museum } \\
\text { promotes audio guides instead of sightseeing } \\
\text { services. Excursion services are performed } \\
\text { on a contractual basis with private guides }\end{array}$ \\
\hline
\end{tabular}

Source: $[14 ; 15]$

more for two adults and one child, by $70 \%$ more for two adults and three children. Management of the National Museum of the History of Ukraine in the Second World War has diverse discount schedule, for example, for students, school children and pensioners: the price policy is museum strength.

The above museums stimulate persons with disabilities to visit them. It is developed the product for children who had poor eyesight in the Second World War in Kyiv. It was created more comfortable conditions for the persons with musculoskeletal disorders and vision impairments for visiting the museum in Gdansk.

The museum sites have comfortable navigation and simple access to the main functions. The strong points of the Second World War in Kyiv are a soundtrack for the website, possibility of paying the tickets by card or in cash. But capacities of the site of the Second World War in Gdansk site are more relevant for tourists - booking tickets online.

Conclusions from the research and prospects for future studying in this direction. The organization of the tourist services is analyzed on the basis of the comparison of the Second World War Museums in Kyiv and Gdansk. It is established the museum service provision in the National Museum of the History of Ukraine in the Second
World War, and comments are made. The paper marks the museum has got its formed brand, but there is a problem of organization of tourist services. Following foreign museums, it is necessary to upgrade comfort conditions for visitors to enhance ticket cost that is 1 euro, whereas a ticket to the Second World War in Gdansk costs 5.44 euros and other European museums 6 - 25 euros.

The price policy of both museums is conditioned by the microeconomic factors, and prices are oriented on internal tourists. The Second World War Museum in Kyiv has a budget-friendly cost of the ticket, which is equivalent to the price for photo and video shooting, while other European museums propose more expensive ticket price and free photo and video shooting that is more optimal price policy.

It is proposed guided tour services implemented by museum staff in the Second World War Museum in Kyiv, while guided tour services are provided on a contract basis by private guides in the Second World War Museum in Gdansk. For this very reason, there is competition and personal interest among the latter guides in the performance of professional duties at a high level.

In both museums, there are audio guide services which are oriented on tourists, including foreigners. 
The special effort is ticket+audio guide cost $60 \mathrm{UAH}$ in the Second World War Museum in Kyiv (audio guide separately costs $50 \mathrm{UAH}$, together ticket $80 \cup A H$ ).

The first, in the Second World War Museum in Kyiv, it is essential to increase the ticket price and do free photo and video shooting. In general, it would increase cash receipts percent in the structure of museum finances and give enough resources for changes in the museum management.

The second, the museum needs to develop an opportunity for online ticketing that will do visiting memorial complex more comfortable, because it shortens the waiting time, especially for the provision of exclusive service.

The third, the staff hospitality needs observations that's why developing and introduction of an effective control system for staff activity and motivation - factors of psychological and financial stimulus - will make it possible to improve the museum service generally.

The fourth, the texts accompanying museum pieces on the territory of the memorial complex are in Ukrainian, thus foreign tourists have difficulties during visiting exhibitions. For this very reason, English and Russian texts should be added to museum pieces.

\section{БІБЛІОГРАФІЧНИЙ СПИСОК:}

1. Бриггс С. Маркетинг в туризмі. К.: Знання-Прес, 2005. 358 С.

2. Биржаков М.В. Введение в туризм. М. - СПб.: Невская Фундация, Издательский дом «Герд», 2005. 443 с.

3. Кифяк В.Ф. Організація туризму: Навчальний посібник. Чернівці: Книги - XXI, 2011. 344 с.

4. Чорненька Н.В. Організація туристичної індустрії: Навчальний посібник. К.: Атіка, 2006. 264 с.

5. Бабарицька В., Короткова А., Малиновська О. Екскурсознавство і музеєзнавство. Навчальний посібник. К.: Альтерпрес, 2007. 464 с.

6. Горішевський П., Дейнега М., Ковалів М., Мельник В., Рега Н., Оришко С., Соколова О. Основи музеєзнавства, маркетингу та рекламно-інформаційної діяльності музеїв. Посібник. Івано-Франківськ: Плай, 2005. 64 C.

7. Рутинський М.Й., Стецюк О.В. Музеєзнавство: Навчальний посібник. К., 2008. 428 с.

8. Юренева Т.Ю. Музееведение. М.: Академический проект, 2003. 605 с.

9. Савченко А. Конспект музейної зустрічі № 7. Сервіс у музеях / А. Савченко. Prostir.museum : веб-сайт. URL: http://prostir.museum/ua/post/36561. (дата звернення: 01.08.2019).

10. Національний музей історії України в Другій світовій війні. Національний музей історії України у Другій світовій війні. Меморіальний комплекс : веб-сайт.URL: http://www.warmuseum.kiev.ua/index_eng.html (дата звернення: 01.08.2019).

11. Музей Великої Вітчизняної. TripAdvisor : веб-сайт. URL: https://www.TripAdvisor.ru/Attraction_Reviewg294474-d1482747-Reviews-Great_Patriotic_War_Museum-Kiev.html\#review_294643469 (дата звернення: 01.08.2019).

12. Бєлікова М.В. Основи музеєзнавства: навчальний посібник для студентів вищих навчальних закладів / М.В. Бєлікова, В.М. Зайцева. Запоріжжя: ЗНТУ, 2015. 225 с.

13. Національний музей історії України в Другій Світовій війні. Меморіальний комплекс. Izi.travel : вебсайт. URL: https://izi.travel/ru/2ccb-national-museum-of-the-history-of-ukraine-in-the-second-world-war-memorialcomplex/en (дата звернення: 01.08.2019).

14. Museum of the Second World War. Plan your visit. Museum II wojny Swiatowey : веб-сайт. URL: www.muzeum1939.pl (дата звернення: 01.08.2019).

\section{REFERENCES:}

1. Briggs S. Marketing in tourism. K.: Znannya-Pres, 2005. 358 p.

2. Birzhakov M.V. Introduction to tourism. M. - SPb.: Nevsky Foundation, Gerd Publishing House, 2005.443 p.

3. Ky`fyak V. F. Organizaciya tury`zmu: Navchal`ny`j posibny`k. Chernivci: Kny`gy` - XXI, 2011. 344 p.

4. Chornen`ka N.V. Organizaciya tury`sty`chnoyi industriyi: Navchal`ny`j posibny`k. K.: Atika, 2006. 264 p.

5. Babary`cz`ka V. Ekskursoznavstvo i muzeyeznavstvo: Navchal’ny j posibny`k / V. Babary`cz`ka, A. Korotkova, O. Maly`novs`ka. K.: Al’terpres, 2007. - 464 p.

6. Horishevs'kyy, P., Deyneha, M., Kovaliv, M. et all (2005) Osnovy muzeyeznavstva, marketynhu ta reklamno-informatsiynoyi diyal'nosti muzeyiv: posibnyk. Ivano-Frankovsk: Play.

7. Rutyns'kyy, M.Y., Stetsuk, O.V. (2008) Muzeyeznavstvo: Navchal'nyy posibnyk. Kyiv: Znannya.

8. Yureneva T.Yu. Museology / T.Yu. Yureneva. M.: Academic project, 2003. - 605 p.

9. Savchenko A. Abstract of the museum meeting No. 7. Service in museums. Available at: http://prostir.museum/ ua/post/36561. [Accessed 9 August. 2019].

10. National Museum of the History of Ukraine in the Second World War. [online] National Museum of the History of Ukraine in the Second World War. Memorial complex. Available at: http://www.warmuseum.kiev.ua/index_eng. html [Accessed 9 August. 2019]. 
11. Great Patriotic War Museum. [online] TripAdvisor. Available at: https://www.TripAdvisor.ru/Attraction Review-g294474-d1482747-Reviews-Great_Patriotic_War_Museum-Kiev.html\#review_294643469 [Accessed 1 August. 2019].

12. Byelikova, M.V., Zaytseva, V.N. (2015) Osnovy muzeyeznavstva: navchal'nyy posibnyk dlya studentiv vyshchykh navchal'nykh zakladiv. Zaporizhzhia: "LIPS" LTD.

13. National Museum of the History of Ukraine in the Second World War. Memorial complex. [online] Izi.travel. Available at: https://izi.travel/ru/2ccb-national-museum-of-the-history-of-ukraine-in-the-second-world-war-memorialcomplex/en [Accessed 9 August. 2019].

14. Museum of the Second World War. Plan your visit [online] Museum II Wojny Swiatowej. Available at: www.muzeum1939.pl [Accessed 9 August. 2019]. 